\title{
Weaning results of beef Hungarian Fleckvieh calves 1. Environmental factors
}

\author{
FERENC SZABÓ, IMRE FÜLLER, ATTILA FÖRDÖS and SZABOLCS BENE \\ Georgikon Faculty, University of Pannonia, Keszthely, Hungary
}

\begin{abstract}
Weaning performance of 7032 purebred Hungarian Fleckvieh calves (3650 male and 3382 female) born between 1981 and 2003 from 1452 cows mated with 113 sires were analysed in two farms. The aim of the study was to evaluate the effect of environmental factors on weaning traits. Farm, age of cows, year of birth, season of birth and sex of calves as fixed, while sire as a random effect was treated. Data were analysed with HARVEY's (1990) Least Square Maximum Likelihood Computer Program. The overall mean value and standard error of weaning weight, preweaning daily gain and 205-day weight were $214 \pm 3.01 \mathrm{~kg}, 980 \pm 17.31 \mathrm{~g} /$ day and $236 \pm 3.40 \mathrm{~kg}$, respectively. The mean age of the analysed calves was $181 \pm 33$ days. The results of the examination show that weaning weight, preweaning daily gain and 205-day weight increased as far as the 6 year age cows (the maximum were $226 \pm 3.13 \mathrm{~kg}, 1049 \pm 17.89 \mathrm{~g} / \mathrm{day}, 251 \pm 3.54 \mathrm{~kg}$ ). As for the season effect the calves born in summer were smaller $(208 \pm 3.12 \mathrm{~kg}, 946 \pm 17.84 \mathrm{~g} /$ day and $230 \pm 3.52 \mathrm{~kg})$ than that of born in the other seasons $(P<0.001)$. The male calves were heavier than females, the difference was $12 \mathrm{~kg}, 50 \mathrm{~g} /$ day, $16 \mathrm{~kg}$, respectively $(P<0.001)$. The best year was 1985, the worst 2000.
\end{abstract}

Keywords: beef cattle, weaning weight, age effect, year effect, season effect, Hungarian Fleckvieh

\section{Zusammenfassung}

\section{Absetzergebnisse ungarischer Fleckviehkälber 1. Umweltfaktoren}

Es wurden in zwei Beständen die Absetzergebnisse von 7032 zwischen 1981 und 2003 geborenen ungarischen Fleckviehkälbern (3 650 männliche und 3382 weibliche) von 113 Vätern und 1452 Müttern untersucht. Geprüft wurde der Einfluss unterschiedlicher Umwelten auf das Absatzgewicht. Dabei wurden als fixe Effekte Betrieb, Abkalbungsalter der Kühe, Jahr und Jahreszeit der Geburt sowie das Geschlecht und als zufälliger Effekt der Vater berücksichtigt. Für die Berechnungen stand das HARVEY's (1990) Least Square Maximum Likelihood Computerprogramm zur Verfügung. Die Mittelwerte und Standardabweichungen betrugen beim Absetzgewicht, der täglichen Zunahme bis zum

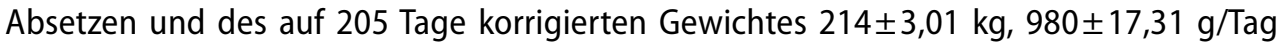
und $236 \pm 3,40 \mathrm{~kg}$. Das durchschnittliche Absetzalter der Kälber lag bei $181 \pm 33$ Tagen. Alle drei untersuchten Merkmale der Kälber zeigten im Zusammenhang mit dem Alter 
der Mütter eine Erhöhung bis zu einem Alter der Mütter von 6 Jahren. Das Maximum dieser Merkmale lag bei $226 \pm 3,13 \mathrm{~kg}, 1049 \pm 17,89 \mathrm{~g} / \mathrm{Tag}$ bzw. $251 \pm 3,54 \mathrm{~kg}$. Im Sommer geborene Kälber erreichten signifikant geringere Werte $(208 \pm 3,12 \mathrm{~kg}, 946 \pm 17,84 \mathrm{~g} / \mathrm{Tag}$ bzw. $230 \pm 3,52 \mathrm{~kg}$ ). Der Geschlechterunterschied war signifikant und betrug $12 \mathrm{~kg}, 50 \mathrm{~g} / \mathrm{Tag}$ bzw. $16 \mathrm{~kg}$ zugunsten der männlichen Kälber. Bei Betrachtung der drei Merkmale erreichte der Jahrgang 1981 die besten und 2000 die schlechtesten Ergebnisse.

Schlüsselwörter: Fleischrind, Absetzgewicht, Alterseffekt, Jahreseffekt, Jahreszeiteffekt, Ungarisches Fleckvieh

\section{Introduction}

The Hungarian Fleckvieh is a breed in Hungary for dual and beef purpose as well. For the beef cattle the good calf rearing ability over the good reproduction capacity are important. The weaned calf is the only product of beef cattle sector; therefore the results are influenced by weaning weight. The weaning weight expresses the inherited growth traits of the calf and the calf rearing ability of cows, so it is very important to have profound knowledge about the environmental and other factors, which have an influence on weaning weight.

Based on the conformation, beef production can be better estimated than other production properties. The heritability of the body measurements is medium (VAN MARLE-KÖSTER et al. 2000, LENGYEL et al. 2003).

In addition to the hereditary base the growth of the calves and their weight at a given age are influenced by breed, farm, age of dam, year, and season of birth and sex of the calves (GREGORY et al. 1979, BÖLCSKEY et al. 1984, SZABÓ 1993, TÖZSÉR et al. 1996, GÁSPÁRDY et al. 1998, TAWFIK et al. 2000, GOYACHE et al. 2003, ZÁNDOKl et al. 2003, NAGY et al. 2004, ATIL et al. 2005, SZABÓ et al. 2005, Vostrý et al. 2008).

The effect of the age of dams was evaluated by BÖLCSKEY (1987) in Hereford and Angus, by SZABÓ and GAJDI (1993) in Hereford, by LENGYEL et al. (2003) in Limousin populations. These authors report that the adjusted weaning weight of the calf increases as far as the age of dams until the 3rd calving, and it decreases from the 11th calving. In the weaning weights of the calves, born from the 3rd to the 10th calving there wasn't any reliable difference.

The weaning result of the calves, born in August and September falls by $11.6 \%$ behind the calves, born between February and April. The weaning weight of the calves in a Limousin population born in the autumn was the highest (KOVÁCS et al. 1994).

The relating examinations report about a significant difference between the two sexes. The male calves showed a greater adjusted weaning weight, than the female calves.

The aim of the present examination was to evaluate the effect of some environmental factors on the weaning results of Hungarian Fleckvieh calves.

\section{Material and methods}

The examination were made on the basis of the data of 7032 calves ( 3650 male and 3382 female) of 113 breeding bulls born between 1981 and 2003. The database was given by 
the Association of Hungarian Fleckvieh Breeders and two farms, which breed beef Hungarian Fleckvieh.

The evaluated traits were weaning weight, preweaning daily gain and 205-day weight.

The effect of the several environmental factors was estimated by a sire model (SZÖKE and KOMLÓSI 2000). The used models included fixed effects (environmental effects) and random genetic effect (sire).

The Table 1 shows the models, which were applied for estimating the effect of the traits. From the factors examined the farm, the calving age of the cow, year and season of birth and sex were as fixed effects, while the sire as a random genetic effect. The age of calves - from the birth to the weaning - was treated as a co varying effect in case of the weaning weight and the preweaning daily gain. Only the significant determinants were put into the model.

Table 1

The statistical models for estimation

Die für die Schätzung verwendeten statistischen Modelle

\begin{tabular}{|c|c|c|c|c|}
\hline Source of variance & Classes & Weaning weight & Preweaning daily gain & 205-day weight \\
\hline Sire $(S)$ & 113 & $* * * *$ & $* * * *$ & $* * * *$ \\
\hline Farm (F) & 2 & $* * * *$ & $* *$ & $* *$ \\
\hline Age of cows (C) & 15 & $* * * *$ & $* * * *$ & $* * * *$ \\
\hline Year $(\mathrm{Y})$ & 23 & $* * * *$ & $* * * *$ & $* * * *$ \\
\hline Season (E) & 4 & $* * * *$ & $* * * *$ & $* * * *$ \\
\hline $\operatorname{Sex}(I)$ & 2 & $* * * *$ & $* * * *$ & $* * * *$ \\
\hline $\begin{array}{l}\text { Covariant (age of calves } \\
\text { at weaning) }\left(b_{1}\right)\end{array}$ & - & $* * * *$ & $* * * *$ & - \\
\hline
\end{tabular}

${ }^{*} P<0.10,{ }^{* *} P<0.05,{ }^{* * *} P<0.01,{ }^{* * * *} P<0.001$

The general form of the model having been applied for the preweaning daily gain is as follows:

$$
Y_{i j k l m n o}=\mu+S_{i}+F_{j}+C_{m}+Y_{k}+E_{l}+I_{n}+b\left(x_{i j k l m n o}-X\right)+e_{i j k l m n o}
$$

where $Y_{i j k l m n o}$ is the weaning weight, the gain falling to life day of the weaned calf from $i$-th sire in the $j$-th farm, in the $k$-th year $/$ season from the $m$ years old cow, $n$ is the sex and $o$ is the age of the calf, $\mu$ is the mean value of all observations, $S_{i}$ is the random effect of the sire, $F_{j}$ is the fixed effect of the farm, $C_{m}$ is the fixed effect of the calving age of the cow, $Y_{k}$ is the fixed effect of the year of birth, $E_{l}$ is the fixed effect of the season of birth, $I_{n}$ is the fixed effect of the sex, $b$ the regression coefficient, and $e_{i j k l m n o}$ is the residual and error.

The way of evaluating the 205-day weight differs from the former so far as the age of calves as covariant wasn't built into the model. The model was as follows:

$$
Y_{i j k l m n o}=\mu+S_{i}+F_{j}+Y_{k}+E_{l}+C_{m}+I_{n}+e_{i j k l m n o}
$$

Additive and multiplicative factors were calculated by subtraction of the mean value of the levels, where significant deviation between the levels was found.

The preparation of data was made by Microsoft Excel Program the evaluation by HARVEY's (1990) Least Square Maximum Likelihood Computer Program. 


\section{Results and discussion}

According to the investigation results - as it can be seen in the Table 1 - sire, farm, age of cows at calving, year, season, sex and the age of calves at weaning have a significant $(P<0.001$ and $P<0.05)$ influence on weaning weight, preweaning daily gain and 205 -day weight. The contribution of investigated factors to the total variance is presented in Table 2. Maximum effect has sex (70.53 - $64.73-80.98 \%)$, minimum has sire (1.26 - $2.34-1.13 \%)$.

Table 2

The contribution of source of variance to total variance, $\%$ Das Verhältnis der Varianzquellen in der totalen Varianz, $\%$

\begin{tabular}{lccc}
\hline Source of variance & Weaning weight & Preweaning daily gain & 205-day weight \\
\hline Sire & 1.26 & 2.34 & 1.13 \\
Farm & 10.35 & 1.65 & 1.30 \\
Age of cows & 8.04 & 13.53 & 8.43 \\
Year & 4.77 & 8.90 & 3.73 \\
Season & 5.05 & 8.85 & 4.43 \\
Sex of calf & 70.53 & 64.73 & 80.98 \\
\hline
\end{tabular}

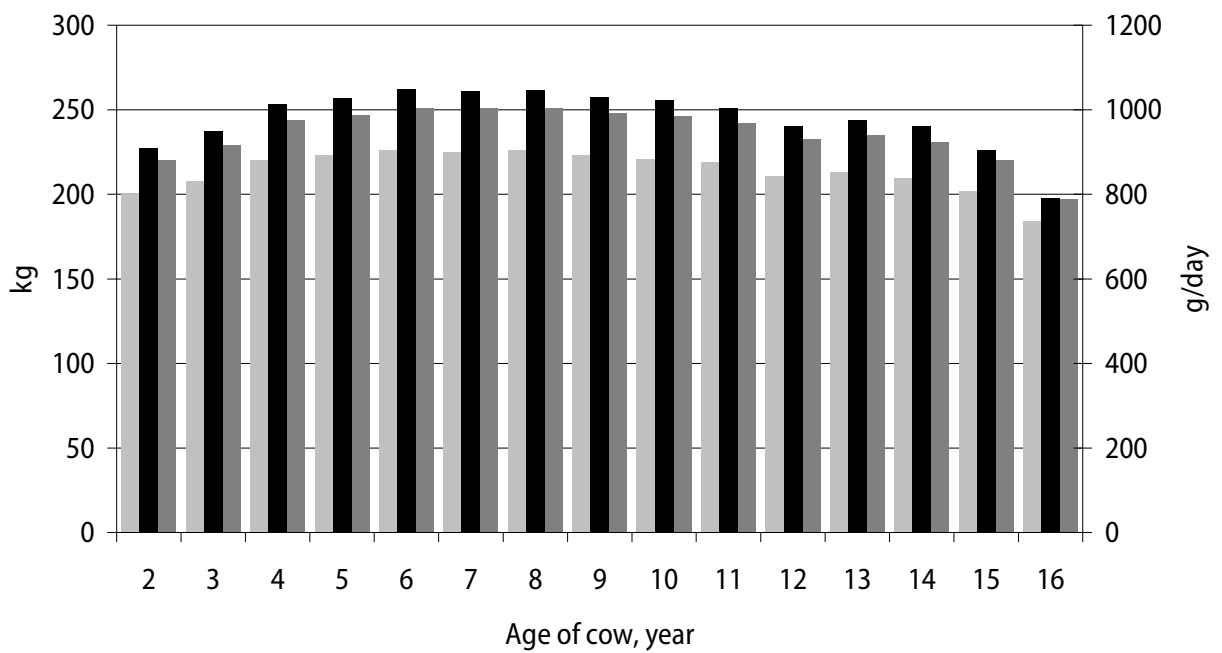

weaning weight $\quad$ 205-day weight $\quad$ preweaning daily gain

Figure 1

The effect of the age of cows on weaning results of calves

Der Einfluss des Alters der Kühe auf die Absetzergebnisse der Kälber

These results are similar to the investigations of LENGYEL et al. (2003), but they partly deviate from the results of NAGY et al. (2004) and KOVÁCS et al. (1994).

The effects of environmental factors, which have an influence on the investigated traits, are presented in Table 3. The effect of the farm appears in the better weaning results of farm »A«. The weaning weight was higher in farm »A« by $+10 \mathrm{~kg}$, the preweaning daily gain by $+17 \mathrm{~g} /$ day, and the 205 -day weight by $+4 \mathrm{~kg}$ than those in the farm $» B \ll$. 
Table 3

The effects of the environmental factors on weaning results (mean $\pm \mathrm{SE}$ )

Der Einfluss der Umweltfaktoren auf die Absetzergebnisse (Durchschnitt $\pm S E$ )

\begin{tabular}{|c|c|c|c|c|c|}
\hline \multicolumn{2}{|l|}{ Effects } & $\mathrm{n}$ & Weaning weight, kg & $\begin{array}{l}\text { Preweaning daily } \\
\text { weight, g/day }\end{array}$ & 205-day weight, kg \\
\hline \multicolumn{2}{|l|}{ Overall mean value } & 7032 & $214 \pm 3.01$ & $980 \pm 17.31$ & $236 \pm 3.40$ \\
\hline \multirow[t]{2}{*}{ Farm } & $A$ & 1224 & $219 \pm 3.17$ & $988 \pm 18.10$ & $238 \pm 3.58$ \\
\hline & $\mathrm{B}$ & 5808 & $209 \pm 3.03$ & $971 \pm 17.39$ & $234 \pm 3.42$ \\
\hline \multirow[t]{15}{*}{ Age of cow, year } & 2 & 726 & $200 \pm 3.18$ & $910 \pm 18.19$ & $220 \pm 3.60$ \\
\hline & 3 & 813 & $208 \pm 3.12$ & $950 \pm 17.85$ & $229 \pm 3.52$ \\
\hline & 4 & 902 & $220 \pm 3.09$ & $1013 \pm 17.73$ & $244 \pm 3.50$ \\
\hline & 5 & 802 & $223 \pm 3.11$ & $1028 \pm 17.82$ & $247 \pm 3.52$ \\
\hline & 6 & 755 & $226 \pm 3.13$ & $1049 \pm 17.89$ & $251 \pm 3.54$ \\
\hline & 7 & 690 & $225 \pm 3.14$ & $1044 \pm 17.98$ & $251 \pm 3.56$ \\
\hline & 8 & 605 & $226 \pm 3.17$ & $1047 \pm 18.13$ & $251 \pm 3.59$ \\
\hline & 9 & 489 & $223 \pm 3.23$ & $1031 \pm 18.43$ & $248 \pm 3.66$ \\
\hline & 10 & 409 & $221 \pm 3.28$ & $1024 \pm 18.70$ & $246 \pm 3.71$ \\
\hline & 11 & 313 & $219 \pm 3.37$ & $1004 \pm 19.16$ & $242 \pm 3.82$ \\
\hline & 12 & 219 & $211 \pm 3.55$ & $961 \pm 20.08$ & $233 \pm 4.02$ \\
\hline & 13 & 146 & $213 \pm 3.81$ & $975 \pm 21.43$ & $235 \pm 4.32$ \\
\hline & 14 & 90 & $210 \pm 4.25$ & $961 \pm 23.80$ & $231 \pm 4.84$ \\
\hline & 15 & 55 & $202 \pm 4.91$ & $904 \pm 27.30$ & $220 \pm 5.60$ \\
\hline & 16 & 18 & $184 \pm 7.45$ & $791 \pm 40.87$ & $197 \pm 8.51$ \\
\hline \multirow[t]{4}{*}{ Season } & Winter & 905 & $214 \pm 3.15$ & $991 \pm 18.01$ & $239 \pm 3.56$ \\
\hline & Spring & 3227 & $215 \pm 3.06$ & $988 \pm 17.53$ & $238 \pm 3.45$ \\
\hline & Summer & 1386 & $208 \pm 3.12$ & $946 \pm 17.84$ & $230 \pm 3.52$ \\
\hline & Autumn & 1514 & $218 \pm 3.12$ & $992 \pm 17.84$ & $238 \pm 3.52$ \\
\hline \multirow[t]{2}{*}{ Sex } & Male & 3650 & $220 \pm 3.03$ & $1005 \pm 17.40$ & $244 \pm 3.42$ \\
\hline & Female & 3382 & $208 \pm 3.04$ & $955 \pm 17.43$ & $228 \pm 3.43$ \\
\hline \multicolumn{3}{|l|}{ Covariant $\left(b_{1}\right)$} & $0.74 \pm 0.01$ & $-1.26 \pm 0.07$ & - \\
\hline
\end{tabular}

In the examined two herds the age of cows at calving changed between 2 and 16 years. According to the results the weaning weight $(226 \pm 3.13)$, the preweaning daily gain $(1049 \pm 17.89)$ and the 205 -day weight $(251 \pm 3.54)$ increased together with the increasing of the age of cows until 6 years. The calves of 7-8 years old cows didn't differ from the calves of 6 years old cows. In the present study a continued decrease was found in case of calves of elder cows (the said tendency is presented in the Figure 1). On the basis of the examinations it is to verify that the calves of older cows reach better weaning weights than the calves born from the first calving. These results agree with the results of BÖLCSKEY (1987), SZABÓ and GAJDI (1993), LENGYEL et al. (2003), NAGY et al. (2004), as well as SZABÓ et al. (2005), who found a similar tendency.

In the course of investigating the effect of birth season, the lowest weaning weight $(208 \pm 3.12 \mathrm{~kg})$, preweaning daily gain $(946 \pm 17.84 \mathrm{~g} /$ day $)$ and 205 -day weight $(230 \pm 3.52)$ were found at the calves born in the summer. The results of calves born in the three other seasons didn't differ significantly from each other (weaning weight $=214-218 \mathrm{~kg}$; preweaning daily gain $=988-992 \mathrm{~g} /$ day; 205 -day weight $=238-239 \mathrm{~kg}$ ). The deviation which was found at the results of summer-calves is correct owing to the error (SE). These 
statements are similar to the results of BÖLCSKEY (1984), KOVÁCS et al. (1994), and SZABÓ and GAJDI (1993), but they differ from the results of SZABÓ et al. (2005), who found the weaning weight of summer-calves the highest.

As for the effect of sex the better weaning results were reached by the bulls, their weaning weight was by $+12 \mathrm{~kg}$, the preweaning daily gain by $+50 \mathrm{~g} /$ day, and the 205-day weight by $16 \mathrm{~kg}$ more than these of the heifers. The difference between the two sexes was similar to the investigations of SZABÓ and GAJDI (1993), KOVÁCS et al. (1994), LENGYEL et al. (2003), NAGY et al. (2004), and SZABÓ et al. (2005).

The Table 4 shows the effect of the year. In case of the weaning weight, the preweaning daily gain and the 205-day weight, 1985 was the best year (245 kg, $1138 \mathrm{~g} / \mathrm{day}, 265 \mathrm{~kg}$ ), while 2000 was the worst $(168 \mathrm{~kg}, 759 \mathrm{~g} /$ day, $191 \mathrm{~kg})$. In the present study the effect of the year is similar to the results of several authors: BÖLCSKEY (1984), TÖZSÉR et al. (1996).

Table 4

The effect of the year on investigated traits (mean $\pm \mathrm{SE}$ )

Der Einfluss des Jahrgangs auf die untersuchten Merkmale (Durchschnitt \pm SE)

\begin{tabular}{|c|c|c|c|c|c|}
\hline Effect & & $\mathrm{n}$ & Weaning weight, kg & $\begin{array}{l}\text { Preweaning daily } \\
\text { gain, g/day }\end{array}$ & 205-day weight, kg \\
\hline Overall mean value & & 7032 & $214 \pm 3.01$ & $980 \pm 17.31$ & $236 \pm 3.40$ \\
\hline \multirow[t]{23}{*}{ Year } & 1981 & 244 & $240 \pm 5.65$ & $1131 \pm 31.23$ & $262 \pm 6.44$ \\
\hline & 1982 & 300 & $228 \pm 5.68$ & $1066 \pm 31.39$ & $251 \pm 6.48$ \\
\hline & 1983 & 327 & $231 \pm 4.72$ & $1074 \pm 26.27$ & $254 \pm 5.37$ \\
\hline & 1984 & 341 & $235 \pm 4.38$ & $1083 \pm 24.44$ & $250 \pm 4.96$ \\
\hline & 1985 & 328 & $245 \pm 4.53$ & $1138 \pm 25.27$ & $265 \pm 5.15$ \\
\hline & 1986 & 329 & $241 \pm 4.63$ & $1123 \pm 25.79$ & $257 \pm 5.25$ \\
\hline & 1987 & 345 & $235 \pm 4.42$ & $1089 \pm 24.68$ & $255 \pm 5.03$ \\
\hline & 1988 & 448 & $235 \pm 4.12$ & $1083 \pm 23.08$ & $252 \pm 4.67$ \\
\hline & 1989 & 416 & $227 \pm 4.16$ & $1012 \pm 23.28$ & $240 \pm 4.70$ \\
\hline & 1990 & 272 & $226 \pm 4.28$ & $1021 \pm 23.95$ & $252 \pm 4.87$ \\
\hline & 1991 & 343 & $214 \pm 4.72$ & $951 \pm 26.25$ & $238 \pm 5.37$ \\
\hline & 1992 & 294 & $209 \pm 4.04$ & $920 \pm 22.65$ & $229 \pm 4.59$ \\
\hline & 1993 & 197 & $200 \pm 4.46$ & $876 \pm 24.91$ & $226 \pm 5.07$ \\
\hline & 1994 & 282 & $229 \pm 4.32$ & $1062 \pm 24.12$ & $254 \pm 4.91$ \\
\hline & 1995 & 319 & $217 \pm 4.24$ & $1020 \pm 23.75$ & $250 \pm 4.82$ \\
\hline & 1996 & 289 & $200 \pm 4.25$ & $903 \pm 23.78$ & $226 \pm 4.83$ \\
\hline & 1997 & 282 & $193 \pm 4.59$ & $883 \pm 25.58$ & $219 \pm 5.23$ \\
\hline & 1998 & 250 & $189 \pm 4.72$ & $852 \pm 26.27$ & $214 \pm 5.37$ \\
\hline & 1999 & 254 & $185 \pm 4.77$ & $835 \pm 26.51$ & $208 \pm 5.43$ \\
\hline & 2000 & 269 & $168 \pm 4.83$ & $759 \pm 26.85$ & $191 \pm 5.50$ \\
\hline & 2001 & 358 & $194 \pm 4.79$ & $893 \pm 26.66$ & $220 \pm 5.46$ \\
\hline & 2002 & 309 & $196 \pm 4.80$ & $913 \pm 26.69$ & $220 \pm 5.47$ \\
\hline & 2003 & 236 & $185 \pm 4.95$ & $844 \pm 27.47$ & $204 \pm 5.64$ \\
\hline
\end{tabular}

The Table 5 shows the additive and multiplicative factors for correction of the environmental effects which was worked out on the basis of the results, referred to the weaning weight, preweaning daily gain and 205-day weight. In case of the 205-day weight e.g. it can be corrected the weight of the calves of 2 years old cows by adding +28 $\mathrm{kg}$ to it, or it can be corrected that by multiplying with 1.127 . The corrections values, which were verified in the investigated population can give standards to the other farms. 
Table 5

Calculated additive and multiplicative correction factors Kalkulierte additive und multiplikate Korrektfaktoren

\begin{tabular}{lccccccc}
\hline \multirow{2}{*}{ Effects } & \multicolumn{3}{c}{ Weaning weight, $\mathrm{kg}$} & \multicolumn{2}{c}{ Preweaning daily gain } & \multicolumn{2}{c}{ 205-day weight, $\mathrm{kg}$} \\
& & Additive & Multiplicative & Additive & Multiplicative & Additive & Multiplicative \\
\hline \multirow{2}{*}{ Age of cows, year } & 2 & +23 & 1.115 & +120 & 1.132 & +28 & 1.127 \\
& 3 & +15 & 1.072 & +80 & 1.084 & +19 & 1.083 \\
& $4-11$ & +0 & 1.000 & +0 & 1.000 & +0 & 1.000 \\
& $12-14$ & +12 & 1.057 & +64 & 1.066 & +15 & 1.064 \\
& 15 & +21 & 1.104 & +126 & 1.139 & +28 & 1.127 \\
\multirow{4}{*}{ Season } & 16 & +39 & 1.212 & +239 & 1.302 & +51 & 1.259 \\
& Winter & +0 & 1.000 & +0 & 1.000 & +0 & 1.000 \\
& Spring & +0 & 1.000 & +0 & 1.000 & +0 & 1.000 \\
& Summer & +8 & 1.038 & +44 & 1.047 & +8 & 1.035 \\
\multirow{4}{*}{ Sex } & Autumn & +0 & 1.000 & +0 & 1.000 & +0 & 1.000 \\
& Male & +0 & 1.000 & +0 & 1.000 & +0 & 1.000 \\
& Female & +12 & 1.058 & +50 & 1.052 & +16 & 1.070 \\
\hline
\end{tabular}

Summing up the results of the analysis of the evaluated factors i.e. farm, age of cows, year, season and sex of the calf brought significant $(P<0.001, P<0.05)$ differences in the weaning results of Hungarian Fleckvieh calves. According to the detailed examination of the environmental factors it can state that the weaning weight, preweaning daily gain and 205-day weight of the calves increased as far as the six year age cows and they didn't differ from the calves of 7-8 years old cows. As for the effect of the season, the calves born in the winter, spring, or autumn didn't differ from each other in the weaning weight, but they were certainly bigger then those from the summer calving. The effect of sex showed itself - as it was expected - in the better weaning results of the bull calves. According to the investigations the present study shows that considering the several environmental factors it is practical to correct the weaning results of calves born in the summer and coming from 2, 3, or 12-16 years old cows in order to make the comparison more exact.

\section{References}

Atil H, Khattab AS, Badawy L (2005) Genetic parameter of birth and weaning weights for Friesian calves by using an animal model. Arch Tierz 48, 261-9

Bölcskey K (1984) Weaning performance and live weight of beef cows, which calved in the months of the spring high season. Hung J Anim Prod 33, 507-11 [in Hungarian]

Bölcskey K (1987) Changing of calf rearing ability as a function of the number of calvings. Hung J Anim Prod 36, 305-11 [in Hungarian]

Gáspárdy A, Szabára L, Sváb L, Bodó I (1998) Farm-evaluation of weaning weight of Charolais calves by an individual animal model. Hung J Anim Prod 47, 503-13 [in Hungarian]

Goyache F, Fernandez I, Royo LJ, Alvarez I, Gutierez JP (2003) Factors affecting actual weaning weight, preweaning average daily gain and relative growth rate in Asturian de los Valles beef cattle breed. Arch Tierz 46, 235-43

Gregory KE, Smith GM, Cundiff LV, Koch RM, Laster DB (1979) Characterization of biological types of cattle. Cyle III. Birth and weaning traits. J Anim Sci 48, 271-9

Kovács A, Szücs E, Bori T, Nagynaska E, Völgyi-Csík J (1994) Effect of the month of birth and sex on weaning and 1 year performance of Limousin calves. Hung J Anim Prod 43, 209-211 [in Hungarian] 
Lengyel Z. Komlósi I, Balika S, Major T, Erdei I, Szabó F (2003) Investigation of reproduction and weaning results of Hungarian Limousin herds. 1. Sire model. Hung J Anim Prod 52, 25-38 [in Hungarian]

Nagy B, Bodó I, Gera I, Lengyel Z, Török M, Szabó F (2004) Weaning results of Hungarian Grey populations. Hung J Anim Prod 53, 503-14 [in Hungarian]

Szabó F (1990) Data of reciprocal crossing of Hungarian Fleckvieh and Hereford. Hung J Anim Prod 39, 129-34 [in Hungarian]

Szabó F, Gajdi J (1993) Effect of some factors on the weaning weight of Hereford calves. Hung J Anim Prod 42, 499-505 [in Hungarian]

Szabó F, Bene Sz, Nagy L, Erdei I, Márton D, Török M, Lengyel Z (2005) Effect of some factors on weaning weight of beef calves. Hung J Anim Prod 53, 15-26 [in Hungarian]

Szőke Sz, Komlósi I (2000) Comparing of BLUP models. Hung J Anim Prod 49, 231-46 [in Hungarian]

Tawfik ES, Mohsen MK, Salem AY, El-Awady HG (2000) Study on Friesian herds raised in Egypt and Germany. I. Estimate of non-genetic effects and genetic parameters. Arch Tierz 43, 101-14

Tőzsér J, Dobra L, Domokos Z, Kertész I, Zsoltész S (1996) Evaluation of weaning performance of Charolais calves in a stock-breeding. Hung J Anim Prod 45, 349-57 [in Hungarian]

Van Marle-Köster E, Mostert BE, Van Der Westhuizen J (2000) Body measurement as selection criteria for growth in South African Hereford. Arch Tierz 43, 5-15

Vostry L, Jakubec V, Scholte W, Bjelka M, Bezdicek J, Majzlik I (2008) Analysis of population and heterosis effects in crossbred cattle of Czech Fleckvieh and Beef Simmental parentage for growth traits. Arch Tierz 51, 207-15

Zándoki R, Balázs F, Márton I, Tőzsér J (2003)Weaning results of red and black Angus in a population. Hung J Anim Prod 52, 203-13 [in Hungarian]

Received 9 August 2008, accepted 8 December 2009.

Corresponding author:

FERENC SZABÓ

email: szf@georgikon.hu

Georgikon Faculty, University of Pannonia, Deák Ferenc str. 16. Pf. 71, H-8360 Keszthely, Hungary 